\section{Application for patent opposed}

SIR - As Gluckman et al. recently reported (Nature 382, 108; 1996), European and US research groups are protesting against the application by the US company Biocyte Corporation for a patent, already granted in Europe, on the use of stored haematopoietic cells from umbilical cord blood.

Their complaint, amplified in a News story by Declan Butler (Nature 382, 99; 1996), is based on the belief that the patent is unethical: if these patents are enforced, the use of cord-blood cells for transplantation will not conform to the resolution of the International Society of Transplantation establishing the basic principle that no part of the human body should be commercialized and that donation of organs or cells should be free and anonymous.

Since the patent application was opened to the public in Japan in January 1996, two companies have challenged it. A number of clinicians, scientists and volunteer groups for cord-blood banking will present a written opinion to the Patent Office at the Ministry of International Trade and Industry of Japan opposing the patent. In Japan, there had been almost 800 bone-marrow transplantations from non-relatives through the Japan Marrow Donor Program up to June 1996. Nevertheless, many patients are still waiting to find an HLA-matched donor. At least ten cord-blood transplantations from siblings have been carried out in Japan in the past two years. And there is now a movement to establish a cord-blood bank.

The Bone Marrow Transplantation Research Group organized by the Japanese Ministry of Health and Welfare continues to study the clinical value of cord-blood transplantation. All clinicians and scientists are invited to join this group, which will develop standard protocols, including collection, separation and cryopreservation, as well as standards for clinical applications for safe, successful and ethical transplantation.

Such a movement should not be hindered. We therefore join Gluckman et al. in protesting from an ethical point of view against the granting of this patent to Biocyte Corporation. We are also concerned that this patent may discourage and threaten the activities of non-profit cordblood banks, clinicians, patients, parents and the volunteers who support them.

\section{S. Asano*}

\section{T. Nakahata}

\section{T. A. Takahashi}

Institute of Medical Science,

University of Tokyo,

6-1, 4 Shirokanedai,

Minato-ku, Tokyo 108, Japan

* On behalf of members of the Research Group of Bone Marrow Transplantation 'Group B' of Japan.

\section{Sham review}

SIR - Your News item "Report advises against privatization" (Nature 382, 569; 1996) highlights the secrecy in which the current 'prior options review' of Natural Environment Research Council research institutes is being held. It is not good enough for the Department of Trade and Industry spokeswoman to say that "[r]esearch councils do know what the recommendations are" if they are not allowed to tell us, or even to inform their own institutes. It is not only scientists who have been critical of the process. The chairman of the House of Commons Select Committee on Science and Technology, which has a Conservative majority, has expressed disapproval and written that "we are forced to comment on the basis of hypothesis and rumour" (HC 643 of 1995-96).

One may be forgiven for thinking that the prior options exercise is a sham and that the secrecy in which it is being conducted is to enable ministers to do what they wish (privatize, close down?) even if their experts have recommended otherwise.

\section{Desmond Donovan}

Department of Geological Sciences,

University College London,

Gower Street,

London WC1E 6BT, UK

\section{By any other \\ name...}

SIR - Sir John Houghton's defence of the revision of Chapter 8 of the recent Intergovernmental Panel on Climate Change (IPCC) report (Nature 382, 665; 1996) says at several points that what was done was done in accord with "IPCC procedures". Most will accept that, but is not the important question whether the procedures match the task?

Take much-mentioned 'peer review'. Journals use it to help them decide what will interest their readers, grant-making agencies to decide how best to spend their funds, but IPCC believes that peer review will guide it (and the rest of us) to a consensus on climate change. What if consensus is unattainable?

I share IPCC's suspicion that global warming may be the most serious threat in sight to our civility, but I also believe that IPCC's 'procedures' may do as much harm as good. Most of us now know that greenhouse gases are potentially a problem and also that there are persisting uncertainties about the immediacy of the risk.

What we need is not a periodic restatement of the current approximation to a consensus view addressed to "policy- makers" (civil servants?), but a periodic assessment of the continuing uncertainties in the climate models and a continuing review of the 'peer-reviewed' literature, dissident and otherwise, that carries weight in the research community. That way, in due course, IPCC's authority would not require consensus.

As things are, IPCC should recognize that, however robustly it resists "those with various political agendas", consensusbuilding is inherently a political process whose practitioners are called "spindoctors" in other trades.

\section{John Maddox}

9 Pitt Street,

London W8 4NX, UK

\section{Pseuds' corner}

SIR - Your Daedalus column is, as always, fascinating, but "The highest spin" (Nature 382, 212; 1996) must have caused some other jaws to drop besides mine. As the basis for his newest cleverness, David Jones describes how "rotating winged seeds, such as those of the sycamore tree, have spun sedately to the ground each autumn". The startled reaction occurred because the sycamores that I am familiar with have spherically symmetrical fruit heads (fruit balls typically a little over an inch in diameter) which often persist throughout the winter on the tree and, if they fall, behave, if anything, more like Newton's apple than a helicopter. In the United States and Canada, we see seeds of maple trees (Acer sp.) behaving in the fashion ascribed in the Daedalus column to sycamores.

After some puzzlement about the apparent aberrant reproductive behaviour of English sycamores, I concluded that this is - again - an international misunderstanding based on nomenclature differences, and that Jones is referring to a type of maple (Acer pseudoplatanus) while what we in North America call a sycamore is a type of plane tree (Platanus occidentalis).

Incidentally, it turns out that there is yet another type of tree called a sycamore, the sycamore tree mentioned in the Bible, which is a fig tree (Ficus sycomorus) of the Near East, which was notable for its use in ancient Egypt for making mummy cases.

Accordingly, may I suggest that, instead of designating his newest invention a "sycacopter", Jones considers renaming it an "acercopter".

\section{Caroline L. Herzenberg}

Decision and Information

Sciences Division,

Argonne National Laboratory,

9700 South Cass Avenue,

Argonne,

Illinois 60439, USA

e-mail: herzenbc@anl.gov 